\title{
PERTANGGUNGJAWABAN SOSIAL UNIVERSITAS: IMPLEMENTASI MODEL CYCLE RELATIONS
}

\author{
Lina Sinatra Wijaya \\ Program Public Relations, Universitas Kristen Satya Wacana \\ lina.sinatra@staff.uksw.edu \\ Krismiyati \\ Program ICT Education, Universitas Kristen Satya Wacana \\ krismi@staff.uksw.edu
}

\begin{abstract}
The competition among Higher Education is getting tougher. They need to do their best in order to maintain their existence and getting more students coming to their institutions. One way to achieve that goal is through carrying out Corporate Social Responsibility (CSR) programs or University Social Responsibility (USR) for university. This study tries to investigate the implementation of 'Cycle Relations' model in CSR to increase the intake of Higher Education. This study involved seven Higher Educations and nineteen High schools in Central Java. In collecting the data, it used a depth-interview method with all the related parties in this study. The result showed that most of the Higher Education institutions have implemented Corporate Social Responsibility program in various ways. Their target audience included the high schools, society, and parents. From the model implementation, it showed that the CSR program did have an impact towards the intake in their institution. However, one important thing to consider is that the role of the teachers at schools was quite significant in influencing the students to choose which university to go. This reflects that although the Higher Education institution have planned and carried out CSR programs according to what the target audiences' need, it does not guarantee that it will have direct impact towards their intake because the influence of teacher is quite significant. It may have a bigger impact in long term as the target audiences know the quality and contribution of the Higher Education institutions.
\end{abstract}

Keywords: CSR, higher education, intake

\begin{abstract}
ABSTRAK
Persaingan antar perguruan tinggi semakin lama semakin ketat sehingga mereka perlu melakukan dan memberikan yang terbaik untuk mempertahankan eksistensinya dan juga untuk menarik mahasiswa. Salah satu cara untuk mencapai tujuan tersebut adalah melalui kegiatan Corporate Social Responsibility (CSR) atau yang lebih dikenal dengan University Social Responsibility (USR). Penelitian ini menyajikan implementasi model Cycle Relations, suatu model USR untuk meningkatkan intake mahasiswa di perguruan tinggi. Penelitian ini melibatkan tujuh perguruan tinggi dan sembilan belas sekolah menengah di Jawa Tengah. Dalam pengumpulan data, penelitian ini menerapkan metoda interview mendalam dengan partisipan. Hasil
\end{abstract}


penelitian menunjukkan bahwa sebagian besar perguruan tinggi yang ada, sudah melakukan kegiatan USR dalam berbagai bentuk kegiatan. Target sasaran untuk kegiatan USR perguruan tinggi tersebut antara lain sekolah menengah, masyarakat langsung dan orang tua siswa. Dari penerapan model yang ada menunjukkan bahwa program USR memiliki dampak terhadap intake suatu perguruan tinggi. Meskipun demikian, ada satu yang perlu diperhatikan yaitu temuan bahwa peran guru di sekolah sangat penting dalam mempengaruhi siswa di sekolah menengah dalam menentukan perguruan tinggi pilihan mereka. Hal ini menunjukkan bahwa kegiatan USR yang telah direncanakan tidak selalu memberikan dampak langsung terhadap intake dikarenakan pengaruh guru di sekolah cukup signifikan. Kegiatan USR bisa saja memberikan dampak besar tetapi dalam jangka waktu yang lebih panjang karena target sasaran perlahan-lahan mengetahui kualitas dan kontribusi perguruan tinggi tersebut.

Kata kunci: pertanggungjawaban sosial, pendidikan tinggi, intake

\section{PENDAHULUAN}

Corporate Social Responsibility (CSR) atau pertanggungjawaban sosial memang sedang menjadi trend di Indonesia. CSR dilakukan oleh perusahaanperusahaan di Indonesia dan juga institusi-institusi pendidikan di Indonesia. Selain itu, melalui Undang Undang No. 40 tahun 2007 tentang CSR khususnya pasal 74 (Pemerintah Republik Indonesia 2007) juga mewajibkan pelaku usaha untuk melaksanakan tanggung jawab sosial termasuk perguruan tinggi. Istilah CSR di dunia pendidikan lebih dikenal dengan USR yaitu University Social Responsibility atau disebut juga tanggung jawab sosial universitas, yang merupakan analogi dari istilah Corporate Social Responsibility dengan menimbang bahwa istilah CSR bagi perguruan tinggi/universitas yang merupakan lembaga nirlaba kurang tepat, maka digunakan istilah university untuk menggantikan kata corporate sebagai padanannya (Widyantoro \& Subhan 2009).

Universitas/perguruan tinggi (PT) sekarang ini sudah dianggap sebagai sebuah institusi pendidikan yang serba bisa, sudah pasti dan juga lebih dapat dipercaya dalam menjawab permasalahan dan perubahan yang terjadi dalam kehidupan masyarakat. Oleh karena itu, sekarang ini banyak perguruan tinggi yang melakukan kegiatan USR dalam berbagai bentuk kegiatan yang bisa memberi kontribusi terhadap para stakeholders yang ada. Kegiatan USR yang dilakukan oleh perguruan tinggi ini lebih sering dikenal dengan kegiatan pengabdian kepada masyarakat, dalam hal ini lebih dikhususkan pada stakeholder perguruan tinggi tersebut. Kegiatan USR atau pengabdian masyarakat yang telah dilakukan oleh perguruan tinggi dan dapat dijumpai dalam masyarakat pun beragam mulai dari pelatihan untuk guru-guru Bimbingan Konseling (BK) di sekolah-sekolah, seminar bagi siswa sekolah menengah, maupun kegiatan yang menyentuh masyarakat secara umum seperti kegiatan penyuluhan dan pelatihan untuk Usaha Mikro Kecil Menengah (UMKM) ataupun untuk target masyarakat tertentu seperti ibu menyusui, ibu-ibu hamil, ataupun pelaku industri 
rumah tangga. Hal ini menunjukkan bahwa memang perguruan tinggi merupakan bagian yang tak terpisahkan dari kehidupan masyarakat baik secara langsung maupun tidak langsung.

Peran perguruan tinggi dalam masyarakat tidak bisa dipungkiri lagi dalam berbagai bidang baik yang membawa dampak secara langsung maupun tidak. Salah satunya adalah kontribusi yang diberikan baik melalui lulusan yang dicetak ataupun kegiatan yang bersinggungan dengan kehidupan masyarakat secara langsung. Kegiatan tersebut bisa berupa program pengabdian kepada masyarakat yang dapat dikatakan program tanggung jawab sosial universitas (USR).

Program USR ini juga merupakan bagian dari program Public Relations untuk mempertahankan eksistensinya ditengah persaingan antar perguruan tinggi swasta yang semakin ketat. Program USR ini berdampak terhadap berbagai hal diantaranya citra yang dimiliki oleh institusi dan yang tidak kalah penting adalah pengaruh terhadap intake suatu perguruan tinggi. Satu model yang menjelaskan fenomena USR di Jawa Tengah adalah cycle relations (Wijaya \& Krismiyati 2014). Pada dasarnya model ini menekankan bahwa kegiatan $U S R$ yang dalam hal ini dapat disebut juga dengan istilah pengabdian masyarakat yang dilakukan oleh perguruan tinggi, baik itu oleh dosen, mahasiswa maupun alumni dari suatu perguruan tinggi. Kegiatan tersebut pada akhirnya akan membawa hasil pada perguruan tinggi tersebut dan untuk selanjutnya menjadi input yang diolah menjadi output di tengah masyarakat dan kembali lagi diolah di perguruan tinggi. Jadi melalui siklus yang hampir sama, akhirnya akan meningkatkan intake suatu perguruan tinggi. Penelitian ini mengembangkan riset Wijaya dan Krismiyati (2014) dan bertujuan untuk menyajikan hasil implementasi model cycle relations dalam USR serta mendeskripsikan dampak pelaksanaan program $U S R$ yang dilakukan oleh perguruan tinggi terhadap kenaikan intake masing-masing perguruan tinggi dalam kurun waktu sembilan bulan (dari Januari sampai Oktober tahun 2015) atau satu setengah semester.

\section{KAJIAN PUSTAKA DAN PERUMUSAN HIPOTESIS}

Perguruan tinggi dituntut untuk memberikan kontribusi yang nyata dalam melaksanakan kewajiban sosial terhadap lingkungan dalam rangka meningkatkan kesejahteraan masyarakat dan menjaga keseimbangan hidup ekosistem disekelilingnya. Suhayati (2011) menyatakan bahwa penerapan Corporate Social Responsibility secara tulus akan membuat masyarakat sekitar respek terhadap universitas, citra akan meningkat dan efek positifnya adalah akan lebih dikenal dan disukai masyarakat sehingga daya tarik calon mahasiswa untuk kuliah di universitas tersebut akan semakin tinggi. Hal ini juga dinyatakan Dahan dan Senol (2012) bahwa universitas, khususnya universitas swasta perlu melakukan USR dalam upaya untuk dapat bersaing di dunia pendidikan, karena $U S R$ dapat menjadi salah satu strategi yang akan dilakukan oleh pendidikan tinggi untuk mendapatkan reputasi yang baik. 
Di Indonesia penelitian tentang program $U S R$ di perguruan tinggi dilakukan oleh Daulay (2012) yang mengatakan bahwa suatu perguruan tinggi dalam hal ini universitas jarak jauh (Universitas Terbuka) juga melakukan program USR atau tanggung jawab sosial. Program tersebut selama ini dilakukan dalam bentuk pengabdian kepada masyarakat tidak hanya dilakukan pada lokasi yang jauh, tetapi juga harus difokuskan pada pembangunan di lingkungan sosial dan ekonomi masyarakat sekitar berdasarkan prinsip peacefull co-existence (hidup berdampingan secara damai) dan symbiosis mutualism (hidup saling menguntungkan) antara perguruan tinggi dengan stakeholdernya termasuk masyarakat sekitar perguruan tinggi tersebut.

Perguruan tinggi dituntut untuk memberikan kontribusi yang nyata terutama dalam penyelesaian masalah-masalah sosial yang muncul di dalam masyarakat. Selain itu program USR yang dilaksanakan oleh perguruan tinggi memiliki keuntungan ganda, yaitu program ini bermanfaat bagi masyarakat yang menerima manfaat dan kontribusinya sekaligus. Manfaat bagi perguruan tinggi adalah memberi efek pencitraan. Selain itu, program USR juga memuat secara implisit arah perguruan tinggi dalam masyarakat, apakah hanya murni sebagai lembaga yang berkecimpung dalam dunia akademis semata atau memang mampu menyumbangkan kontribusi yang nyata dan bermanfaat bagi masyarakat (Topal 2009).

Pemodelan USR bagi universitas di Jawa Tengah merupakan cycle relations yang terdiri dari universitas, pengajar/mahasiswa/alumni, masyarakat umum, orang tua dan siswa SMA/SMK. Keterkaitan antara satu dengan yang lain yaitu kemauan untuk mendengar dan merespon inilah yang akan menentukan keberhasilan pelaksanaan program $C S R$ dari perguruan tinggi tersebut, yang nantinya diharapkan akan berimbas pada peningkatan intake dari perguruan tinggi (Wijaya \& Krismiyati 2014).

\section{Perkembangan CSR Di Indonesia}

Sekarang ini program CSR telah menjadi suatu fenomena global, termasuk di Indonesia. Perkembangan pelaksanaan CSR di Indonesia ditandai dengan sudah banyaknya perusahaan yang mengimplementasikan CSR dalam segala bidang. Perusahaan semakin banyak menerapkan CSR baik dalam bentuk amal (charity) maupun pemberdayaan (empowerment) kepada masyarakat (Harahap 2014). Menurut Firdausy (2009), CSR merupakan bentuk kegiatan yang dilakukan pelaku usaha atau organisasi bagi keuntungan (investasi) organisasi tersebut atau perusahaan di satu pihak dan peningkatan kualitas kehidupan masyarakat dan lingkungan di pihak yang lain. Artinya, dengan adanya penerapan $C S R$, masyarakat akan menjadi lebih berdaya baik secara ekonomi, sosial dan budaya secara berkelanjutan (sustainability) sehingga secara tidak langsung perusahaan atau institusi yang melakukan program CSR juga dapat terus berkembang secara berkelanjutan. 
Piramida CSR yang dicetuskan oleh Elkington (1998) yang dikembangkan lagi oleh Carol dalam (Tanudjaja 2006) mengatakan bahwa ada tiga prinsip dasar yang dikenal dengan istilah triple bottom lines dalam pelaksanaan program CSR, yaitu Profit, People dan Planet yang sering disebut dengan istilah 3P. Porter dan Kramer (2002) menjelaskan konsep 3 P sebagai berikut: a. profit, atau disebut juga economic properity / economic responsibility: mendukung laba perusahaan; b. people, atau disebut juga social justice / social responsibility: Meningkatkan kesejahteraan masyarakat dengan cara seperti beramal, pemberian beasiswa bagi pelajar sekitar perusahaan, pendirian sarana pendidikan dan kesehatan; c. planet, atau disebut juga environmental quality/ Environmental Responsibility: Meningkatkan kualitas lingkungan yaitu dalam melaksanakan program CSR ini, perusahaan tetap peduli terhadap lingkungan hidup.

Suatu perusahaan selain mengejar profit, perusahaan juga harus memperhatikan dan terlibat pada pemenuhan kesejahteraan masyarakat (people) dan turut berkontribusi aktif dalam menjaga kelestarin lingkungan (planet). Oleh karena itulah penerapan $C S R$ bukan lagi dirasakan sebagai tanggung jawab tetapi sebagai kewajiban dan harus dilakukan oleh setiap perusahaan (Tanudjaja 2006). Selain itu Pambudi dalam Widyantoro dan Subhan (2009) menyatakan bahwa ada lima pilar konsep CSR, yaitu (1) memiliki sumberdaya manusia yang handal, (2) memberdayakan ekonomi masyarakat, (3) menjaga keharmonisan dengan masyarakat sekitar, (4) perusahaan dikelola dengan birokrasi yang baik dan (5) menjaga kelestarian lingkungan. Dari lima pilar ini semua bertumpu pada institusi dan masyarakat atau dalam hal ini perguruan tinggi dan stakeholder.

\section{Perkembangan $U S R$ di Perguruan Tinggi}

Dalam menerapkan Tri Dharma Perguruan Tinggi, suatu perguruan tinggi perlu menerapkan apa yang disebut dengan tanggung jawab atau dengan istilah tanggung jawab universitas. Semua ini dilakukan sebagai tanggung jawab riil perguruan tinggi di dalam menerapkan Tri Dharma perguruan tinggi guna menyikapi dinamisasi kehidupan.

Bentuk penerapan program USR yang dilakukan perguruan tinggi sedikit berbeda dengan perusahaan. Program $U S R$ dapat diterapkan di segala level akademik universitas. Suatu perguruan tinggi perlu mengadopsi strategi untuk melaksanakan tanggung jawab sosial seperti perusahaan dengan sasarannya lebih ditekankan pada siswa, pemakai lulusan, dan masyarakat termasuk staf administrasi di perguruan tinggi (Nasongkhla et al., 2015). Selain itu juga USR yang dilakukan di Universitas Terbuka Daulay (2012), yang mengatakan bahwa program USR harus difokuskan pada pembangunan di lingkungan sosial dan ekonomi masyarakat sekitar berdasarkan prinsip peaceful co-existence dan symbiosis mutualism. Peran dari program USR bertujuan untuk menunjukkan akuntabilitas dan kredibilitas perguruan tinggi di tengah masyarakat. Program ini juga dilakukan sebagai salah satu upaya untuk meningkatkan 
citra dari perguruan tinggi tersebut. Dari sini terlihat dengan jelas bahwa peran sebuah perguruan tinggi telah berevolusi dari sebuah lembaga akademik yang hanya memberikan layanan akademis menjadi sebuah lembaga yang peka terhadap keberadaan dan kondisi lingkungan dan masyarakat.

Hasil identifikasi Wijaya dan Krismiyati (2014) menunjukkan bahwa sebagian besar perguruan tinggi di Jawa Tengah memberikan pelatihan kepada masyarakat, pelatihan kepada guru sekolah dan administrasi sekolah, juga memberikan beasiswa kepada siswa yang akan belajar di perguruan tinggi. Semua ini dilakukan dalam rangka untuk peningkatan citra dari perguruan tinggi tersebut dan yang nantinya diharapkan akan berimbas pada peningkatan intake perguruan tinggi.

\section{Konsep Intake}

Kata intake berarti sekelompok orang yang masuk ke dalam suatu institusi dalam kurun waktu tertentu (Hornby 1995). Dalam dunia pendidikan, kata ini dapat diartikan sebagai banyaknya jumlah mahasiswa baru yang masuk ke perguruan tinggi dalam tahun akademik tertentu. Oleh karena itu dalam penelitian ini istilah intake yang akan dipakai dimaksudkan sebagai banyaknya jumlah calon mahasiswa baru yang mendaftar masuk ke perguruan tinggi dalam tahun akademik tertentu.

\section{Cycle Relations Model}

Pertama kalinya model ini diadaptasi untuk menggambarkan model CSR bagi perguruan tinggi, sehingga disebut Intake Cycled Relations Model (Wijaya \& Krismiyati 2014), tapi setelah diuji coba dan disempurnakan dalam penelitian ini, model ini selanjutnya akan disebut sebagai Cycle Relations Model. Cycle Relations Model yang dihasilkan dalam penelitian Wijaya dan Krismiyati (2014) ini mengacu teori cycle network (Hanneman \& Riddle 2005; Scott 2000; Carrington, Scott, \& Wasserman 2005). Dalam teori social network, suatu jaringan yang terdiri dari tiga aktor yang memiliki hubungan (tie) disebut sebagai cycle network. Namun demikian yang disebut dengan cycle disini tidak hanya mengacu pada jaringan yang terbangun dari tiga aktor saja tapi bisa juga lebih dari tiga aktor. Model yang digunakan disini adalah tipe jaringan yang terdiri dari empat aktor yang masing-masing aktornya membuat suatu hubungan yang saling mendukung. Cycle dalam model ini berarti bahwa hubungan antar aktor merupakan hubungan yang saling menopang dan mendukung dan menunjukkan siklus kegiatan, dalam hal ini adalah kegiatan CSR yang dilakukan oleh perguruan tinggi (Gambar 1). 


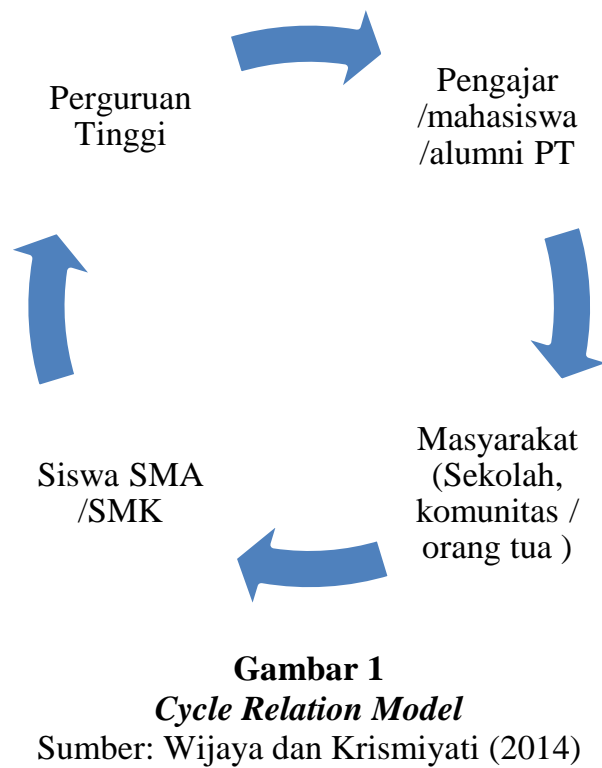

Empat aktor penyusun jaringan dalam model ini adalah perguruan tinggi, alumni atau mahasiswa perguruan tinggi, siswa (SMA/SMK) yang biasanya menjadi target dari pelaksanaan kegiatan, dan yang terakhir adalah intake dari perguruan tinggi. Terlihat dari model ini, peran perguruan tinggi adalah sebagai pencetus kegiatan CSR dan sekaligus sebagai pelaksananya. Dalam penerapanya, perguruan tinggi menggunakan prinsip listen and respond yang berarti bahwa apa yang direncanakan oleh perguruan tinggi dalam upayanya untuk memberi kontribusi terhadap target program CSR mempertimbangkan apa yang menjadi kebutuhan dari target yang akan dituju. Perguruan tinggi biasanya menggunakan mahasiswa/pengajar perguruan tinggi tersebut atau alumni/dari perguruan tinggi tersebut dalam melakukan program $C S R$ nya (Wijaya \& Krismiyati 2014).

Penerapan prinsip listen and respond serta pelaksanaan kegiatan yang berkesinambungan diharapkan mampu menjawab apa yang menjadi kebutuhan dari pemangku kepentingan yang ada. Ketika pemangku kepentingan menerima manfaat dan melihat dampak dari program CSR yang ada makan dengan sendirinya mereka akan dengan suka rela memberi arahan atau masukan yang berimbas pada meningkatnya intake perguruan tinggi. Pendapat, saran dan arahan masyarakat atau sekolah ini biasanya akan berpengaruh terhadap aktor yang keempat yaitu siswa SMA/SMK sebagai calon-calon mahasiswa baru di sebuah perguruan tinggi. Apabila pemangku kepentingan dalam siklus ini saling mendukung satu dengan yang lain, maka langsung ataupun tidak langsung akan berdampak pada intake sebuah perguruan tinggi. Dengan sinergi yang baik, maka keempat unsur dalam model cycle relations ini dapat menjawab permasalahan ketidakpastian dan ketidakjelasan program USR di beberapa perguruan tinggi yang ada di Jawa Tengah. 


\section{METODA PENELITIAN}

Penelitian ini dilakukan selama bulan Januari sampai Oktober tahun 2015 yang melibatkan tujuh perguruan tinggi swasta ataupun negeri dan sembilan belas Sekolah Menengah Umum dan swasta di Jawa Tengah. Semua partisipan dalam penelitian ini mengikuti wawancara mendalam dengan fokus pertanyaan sebagai berikut: a) kegiatan USR yang sudah diterima oleh sekolah dari perguruan tinggi yang ada; b) dampak kegiatan USR yang telah diterima oleh sekolah baik terhadap citra dan juga minat siswa untuk memilih perguruan tinggi tersebut, c) jumlah mahasiswa yang mendaftar di perguruan tinggi secara umum, d) kegiatan USR yang telah dilaksanakan oleh perguruan tinggi, e) respon perguruan tinggi terhadap kebutuhan target sasaran; f) permintaan/kebutuhan target sasaran yang telah diterima oleh perguruan tinggi dalam kurun waktu setahun.

Pertanyaan yang digunakan dalam penelitian ini hanya sebagai acuan namun berkembang sesuai dengan situasi dan kondisi di lapangan ketika melakukan wawancara. Hal ini untuk menjaga agar interview yang dilakukan benar-benar bisa menggali informasi sebanyak mungkin.

Penelitian ini bersifat kualitatif karena menggunakan data yang berupa hasil wawancara yang ditranskripsi untuk lebih lanjut dianalisis datanya. Analisis data dilakukan dengan cara mengelompokkan jawaban wawancara dalam tema-tema yang serupa untuk akhirnya dijadikan bahan interpretasi hasil yang ada. Selain itu analisis data juga dilakukan dengan metoda triangulasi yaitu kesesuaian penerapan program USR yang dilakukan oleh perguruan tinggi tersebut sesuai dengan yang diinginkan para stakeholder atau tidak dan semua ini berimbas pada peningkatan intake dari perguruan tinggi tersebut atau tidak. Peningkatan intake ini dilihat dengan terlihatnya peningkatan jumlah siswa baru yang yang mendaftar pada perguruan tinggi yang telah melakukan program USR tersebut.

Untuk pertimbangan etis, semua partisipan yang terlibat sudah menyatakan kesediaannya dan tidak keberatan untuk ikut serta dalam penelitian. Untuk menjaga kerahasiaan identitas partisipan, dalam analisis data dan pembahasan tidak dicantumkan identitas mereka. Hal ini dilakukan dengan cara memberikan kode seperti PT untuk Perguruan Tinggi, dan HS untuk Sekolah Menengah Umum.

\section{ANALISIS DAN PEMBAHASAN}

\section{Program CSR oleh Perguruan Tinggi}

Dalam kurun waktu sembilan bulan selama penelitian berlangsung semua perguruan tinggi yang terlibat dalam penelitian ini telah melaksanakan kegiatan USR dalam berbagai bentuk. Dalam pelaksanaannya perguruan tinggi selalu melibatkan keterlibatan pihak luar. Dari penerapan program USR yang dilakukan, sebagian besar perguruan tinggi ini menyatakan bahwa program USR sangat berpengaruh pada 
kenaikan intake dari perguruan tinggi. Para siswa maupun guru menjadi semakin mengetahui kualitas dari perguruan tinggi tersebut, misalnya dengan memberikan pelatihan, penyuluhan baik kepada siswa maupun kepada guru sekolah dan masyarakat membuat para stakeholder ini menjadi semakin paham dan tahu akan kemampuan dari perguruan tinggi dalam menyalurkan ilmu pengetahuan maupun keterampilannya kepada mereka.

Para orang tua maupun guru sekolah menjadi semakin yakin bahwa anak didik mereka akan mendapatkan pengetahuan maupun ketrampilan yang sama apabila siswa-siswa mereka menempuh ilmu di perguruan tinggi tersebut. Selain itu siswasiswa sendiri semakin mantap dan percaya bahwa mereka akan mendapatkan apa yang mereka butuhkan apabila menuntut ilmu di tempat tersebut. Pelaksanaan program USR ini sebagian besar berimbas positif pada kenaikan intake dari perguruan tinggi, meskipun masih ada pula yang tidak mengalami kenaikan intake yang dikarenakan tren di era ini sudah mulai berubah, masyarakat lebih memilih untuk menuntut ilmu di sebuah universitas dari pada di sebuah akademi. Dalam pelaksanaannya, perguruan tinggi juga melibatkan para alumni maupun mahasiswa yang masih menuntut ilmu, juga institusi lain yang mendukung pelaksanaan program CSR ini. Program USR yang sudah dilakukan dan keterlibatan pihak lain serta prosentase intake dapat dilihat dalam Tabel 1. 
Tabel 1

Kondisi Program CSR PT

\begin{tabular}{|c|c|c|c|c|}
\hline No & PT & $\begin{array}{c}\text { Jenis Program } C S R \text { yang } \\
\text { dilakukan dalam } 1 \text { tahun ini }\end{array}$ & $\begin{array}{c}\text { Keterlibatan dengan } \\
\text { institusi lain }\end{array}$ & $\begin{array}{c}\text { Prosentase kenaikan } \\
\text { Intake }\end{array}$ \\
\hline 1 & PT 1 & $\begin{array}{ll}\text { - } & \text { Pemberian beasiswa } \\
\text { - } & \text { Pemberian pelayanan kerohanian } \\
& \text { ke ladang ladang baru }\end{array}$ & $\begin{array}{l}\text { Ada - alumni dan } \\
\text { gereja }\end{array}$ & $10-15 \%$ \\
\hline 2 & PT 2 & $\begin{array}{l}\text { - Pelaksanaan donor darah } \\
\text { - Pemberian beasiswa } \\
\text { - Pemberian pelayanan kerohanian } \\
\text { - Pengajaran PAK }\end{array}$ & $\begin{array}{l}\text { Ada - PMI dan rumah } \\
\text { rumah pemulihan }\end{array}$ & $20 \%$ \\
\hline 3 & PT 3 & $\begin{array}{l}\text { - Pemberian penyuluhan kesehatan } \\
\text { - Pemberian beasiswa } \\
\text { - Pelatihan mendeteksi kanker } \\
\text { - } \text { payudara } \\
\text { Pemeriksaan kesehatan }\end{array}$ & $\begin{array}{l}\text { Ada - Alumni sebagai } \\
\text { perantara }\end{array}$ & $\begin{array}{l}0 \% \\
\text { Belum terlihat ada } \\
\text { peningkatan - } \\
\text { disebabkan krn sudah } \\
\text { bukan trend nya lagi }\end{array}$ \\
\hline 4 & PT 4 & $\begin{array}{l}\text { - } \quad \text { Pemberian seminar pembentukan } \\
\text { - } \quad \text { Pelaksanaan donor darah } \\
\text { - Pembersian lingkungan } \\
\text { - Pemberian beasiswa }\end{array}$ & $\begin{array}{l}\text { Ada - PMI dan } \\
\text { Perusahaan JAVA }\end{array}$ & $20 \%$ \\
\hline 5 & PT 5 & $\begin{array}{l}\text { - } \quad \text { Pemberian beasiswa } \\
\text { - } \quad \text { Pelatihan komputer untuk SMA }\end{array}$ & $\begin{array}{l}\text { Ada - Alumni sebatas } \\
\text { sebagai perantara }\end{array}$ & $5-10 \%$ \\
\hline 6 & PT 6 & $\begin{array}{l}\text { - } \\
\text { - } \\
\text { Pemberian beasiswa } \\
\text { pesantren } \\
\text { - } \quad \text { Pelatihan enterpreneurship ke } \\
\text { pedagang kaki lima } \\
\text { - Pelatihan ke guru-guru SMA }\end{array}$ & $\begin{array}{l}\text { Ada - Pesantren, dan } \\
\text { Alumni }\end{array}$ & $5-10 \%$ \\
\hline 7 & PT 7 & $\begin{array}{l}\text { - } \\
\text { - } \\
\text { - } \\
\text { Pelatihan untuk guru BK SMA } \\
\text { maupun staf yang sesuai } \\
\text { konsentrasi fakultas } \\
\text { - } \text { Penyuluhan tentang } \\
\text { pembentukan karakter ke siswa } \\
\text { SMA } \\
\text { - } \\
\text { - } \quad \text { Coaching clinic (basket) }\end{array}$ & $\begin{array}{l}\text { Ada - PMI dan } \\
\text { Alumni }\end{array}$ & $5-10 \%$ \\
\hline
\end{tabular}

\section{Program CSR yang diterima Sekolah}

Dari hasil interview yang diperoleh dari sekolah, dalam setahun ini mereka sudah menerima beberapa macam program USR dari perguruan tinggi yang dapat dilihat dalam Tabel 2. Dari hasil yang diperoleh, semua PT di Jawa Tengah telah melakukan program USR mereka ke SMA/SMK maupun ke masyarakat dalam upaya 
mempromosikan kepada siswa, orang tua, maupun masyarakat tentang apa yang bisa diberikan kepada siswa yang nantinya akan menjadi calon mahasiswa dari PT tersebut dan menunjukkan secara tidak langsung kualitas dari PT tersebut. Dari pelaksanaan program USR ini sebagian besar menunjukkan kenaikan dalam intake mereka sekitar 5-20 persen, meskipun ada satu perguruan tinggi yang tidak mengalami kenaikan, ini dikarenakan tren di jaman ini sudah berpindah pada bidang yang lain.

Sedangkan dari sisi sekolah, terlihat bahwa semua sekolah baik itu SMA maupun SMK telah menerima program USR atau dengan kata lain program pengabdian kepada masyarakat yang dilakukan oleh PT. Bentuk dari program USR yang diberikan memang bermacam-macam sesuai dengan apa yang diperlukan oleh sekolah.

Tabel 2

Macam Program CSR yang diterima Sekolah

\begin{tabular}{|c|c|c|}
\hline No & SMA/SMK & Jenis $C S R$ yang diterima sekolah \\
\hline 1 & HS-1 & $\begin{array}{ll}\text { - } & \text { Pemberian beasiswa } \\
\text { - } & \text { Pelatihan bagi guru BK } \\
\text { - } & \text { Character building } \\
\text { - } & \text { Bimbingan olimpiade } \\
\text { - } & \text { Bimbingan belajar }\end{array}$ \\
\hline 2 & HS-2 & $\begin{array}{l}\text { - Pemberian beasiswa } \\
\text { - } \quad \text { Pelatihan bagi guru BK } \\
\text { - } \quad \text { Penulisan artikel ilmiah untuk guru }\end{array}$ \\
\hline 3 & HS-3 & $\begin{array}{l}\text { - Pemberian beasiswa } \\
\text { - Pelatihan bagi guru BK } \\
\text { - } \quad \text { Bimbingan belajar }\end{array}$ \\
\hline 4 & HS-4 & $\begin{array}{l}\text { - Pemberian beasiswa } \\
\text { - Pelatihan bagi guru BK } \\
\text { - Pelatihan bagi guru tentang pelaksanaan penelitian } \\
\text { - Seminar tentang robot }\end{array}$ \\
\hline 5 & HS-5 & $\begin{array}{ll}\text { - } & \text { Pemberian beasiswa } \\
\text { - } & \text { Pelatihan bagi guru BK } \\
\text { - } & \text { Bimbingan olimpiade } \\
\text { Seminar motivasi untuk siswa }\end{array}$ \\
\hline 6 & HS-6 & $\begin{array}{l}\text { - Pemberian beasiswa } \\
\text { - Pelatihan bagi guru BK } \\
\text { - Pemberian test minat karir } \\
\text { - } \quad \text { Pelatihan } e \text {-book }\end{array}$ \\
\hline 7 & HS-7 & $\begin{array}{l}\text { - } \quad \text { Pemberian beasiswa } \\
\text { - } \quad \text { Pelatihan bagi guru BK } \\
\text { - Training motivasi untuk siswa }\end{array}$ \\
\hline 8 & HS-8 & $\begin{array}{l}\text { - Pemberian beasiswa } \\
\text { - Pelatihan bagi guru BK } \\
\text { - Pendampingan retreat }\end{array}$ \\
\hline 9 & HS-9 & $\begin{array}{l}\text { - } \quad \text { Pemberian beasiswa } \\
\text { - } \quad \text { Pelatihan bagi guru BK } \\
\text { - Pelatihan IT bagi guru }\end{array}$ \\
\hline 10 & HS-10 & $\begin{array}{l}\text { - Pemberian beasiswa } \\
\text { - Pelatihan bagi guru BK }\end{array}$ \\
\hline 11 & HS-11 & - Pemberian beasiswa \\
\hline
\end{tabular}




\begin{tabular}{|c|c|c|}
\hline No & SMA/SMK & Jenis $C S R$ yang diterima sekolah \\
\hline 12 & HS-12 & $\begin{array}{ll}\text { - } & \text { Pelatihan bagi guru BK } \\
\text { - } & \text { Short workshop untuk siswa - photography, desain grafis } \\
\text { - } & \text { Pelatihan PMTK untuk guru } \\
\text { - } & \text { Pemberian beasiswa } \\
\text { - } & \text { Pelatihan bagi guru BK } \\
\text { - } & \text { Character building }\end{array}$ \\
\hline 13 & HS-13 & $\begin{array}{l}\text { - } \quad \text { Pemberian beasiswa } \\
\text { - } \quad \text { Pelatihan bagi guru BK }\end{array}$ \\
\hline 14 & HS-14 & $\begin{array}{ll}\text { - } & \text { Pemberian beasiswa } \\
\text { - } & \text { Pelatihan bagi guru BK } \\
\text { - } & \text { Seminar dan motivasi untuk siswa } \\
\text { - } & \text { Lomba-lomba ketrampilan untuk siswa } \\
\text { - } & \text { Pelatihan LDKM }\end{array}$ \\
\hline 15 & HS-15 & $\begin{array}{ll}\text { - } & \text { Pemberian beasiswa } \\
\text { - } & \text { Pelatihan bagi guru BK } \\
\text { - } & \text { Pelatihan IT untuk guru }\end{array}$ \\
\hline 16 & HS-16 & $\begin{array}{l}\text { - } \quad \text { Pemberian beasiswa } \\
\text { - } \quad \text { Pelatihan bagi guru BK } \\
\text { - } \quad \text { Seminar motivasi untuk siswa } \\
\text { - } \quad \text { Seminar kesehatan mental untuk siswa } \\
\text { - } \quad \text { E-learning untuk guru guru }\end{array}$ \\
\hline 17 & HS-17 & $\begin{array}{l}\text { - } \quad \text { Pemberian beasiswa } \\
\text { - } \quad \text { Pelatihan bagi guru BK } \\
\text { - } \quad \text { Pelatihan akuntansi untuk siswa }\end{array}$ \\
\hline 18 & HS-18 & $\begin{array}{l}\text { - } \quad \text { Pemberian beasiswa } \\
\text { - } \quad \text { Pelatihan bagi guru BK } \\
\text { - } \quad \text { Seminar motivasi untuk siswa }\end{array}$ \\
\hline 19 & HS-19 & $\begin{array}{ll}\text { - } & \text { Pemberian beasiswa } \\
\text { - } & \text { Pelatihan bagi guru BK } \\
\text { - } & \text { Pelatihan matematika } \\
\text { - } & \text { Pelatihan K13 } \\
\text { - } & \text { Seminar motivasi menghadapi UN }\end{array}$ \\
\hline
\end{tabular}

Dari interview yang telah dilakukan dengan sekolah, program USR yang dilakukan sedikit banyak berpengaruh pada keputusan siswa untuk memilih perguruan tinggi yang mana yang akan dimasuki kelak. Hal ini dikarenakan dalam pelaksanaan program USR tersebut, siswa dapat melihat kualitas dari perguruan tinggi tersebut. Dari hasil wawancara yang didapat dari para guru BK dan juga data yang dipantau dari perguruan tinggi terhadap sekolah-sekolah tersebut, rata-rata jumlah siswa yang masuk ke perguruan tinggi, yang melakukan program USR meningkat sekitar 5-15 persen, sebagai contoh, ketika salah satu perguruan tinggi melakukan kegiatan USR yaitu pemberian pelatihan singkat (coaching clinic untuk basket) jumlah siswa yang masuk ke perguruan tinggi tersebut terutama yang berminat pada kegiatan basket meningkat sekitar 15 persen, dari sini terlihat bahwa kegiatan ini dapat menarik minat siswa untuk masuk ke perguruan tinggi tersebut.

Dari hasil penelitian yang sudah dilakukan, terlihat bahwa sebagian besar perguruan tinggi sudah melaksanakan program USR. Dalam pelaksanaannya, 
perguruan tinggi tidak terlepas dari prinsip triple bottom line, pelaksanaan program USR-nya tidak hanya sekedar mengejar keuntungan semata (profit), tetapi kegiatan CSR tersebut harus memenuhi kebutuhan masyarakat sehingga kesejahteraan masyarakat juga tercapai (people). Meskipun demikian, program yang dijalankan juga memperhatikan kesejahteraan lingkungannya (planet). Dengan kata lain, program yang dilaksanakan sudah berhasil memenuhi prinsip profit, people dan planet.

Selain itu dalam pelaksanaannya, semua perguruan tinggi melibatkan pihak luar sehingga program USR yang dilakukan dapat lebih mengena kepada masyarakat, karena agar program $U S R$ berjalan sesuai dengan apa yang diperlukan oleh target sasaran, maka dalam pelaksanaan program USR harus ada keterlibatan langsung dengan target sasarannya bisa melalui yayasan atau organisasi yang lain, bahkan dapat pula bermitra dengan pihak lain. Dengan adanya keterlibatan pihak lain ini juga berimbas pada intake dari perguruan tinggi tersebut. Hampir sebagian besar perguruan tinggi yang melaksanakan program USR ini mengalami kenaikan dalam intake mereka antara 10 persen sampai dengan 15 persen, meskipun ada pula yang tidak mengalami kenaikan, tapi ini disebabkan karena tren di masa sekarang ini sudah beralih ke bidang yang lain, seperti yang dikatakan oleh Altbach, Reisberg, dan Rumbley (2009) bahwa tren akan menentukan perguruan tinggi tersebut dapat bersaing dan ditempatkan dalam kerangka internasional. Jadi sebagai suatu perguruan tinggi, apabila tren dari suatu program studi sudah mulai memudar, perguruan tinggi tersebut harus mencari program promosi dengan inovasi yang baru, yang dapat menarik perhatian dari target sasaran. Inovasi dalam strategi promosi dari suatu perguruan tinggi akan berimbas pada kenaikan intake dari perguruan tinggi tersebut (Wijaya \& Krismiyati 2013).

Dari hasil penelitian dan juga focus group discussion dan diseminasi yang dilakukan, juga ditemukan bahwa satu hal yang terpenting dalam menentukan banyak tidaknya siswa yang akan mendaftar di perguruan tinggi tersebut adalah peran dari guru sekolah terutama peran dari guru BK (Bimbingan Konseling) yang biasanya sangat besar pengaruhnya. Siswa cenderung mendengarkan pada apa yang dikatakan oleh guru BK mereka. Oleh karena itu, dalam melaksanakan program CSR, suatu perguruan tinggi harus melihat apa yang dibutuhkan oleh para guru BK tersebut juga apa yang menjadi kebutuhan para siswa untuk persiapan belajar di perguruan tinggi. Apabila kebutuhannya terpenuhi, maka pengaruh guru BK sangat besar dalam mengarahkan siswanya ke perguruan tinggi tersebut. Untuk mengetahui apa yang dibutuhkan oleh sekolah dalam hal ini melalui guru BK, maka pihak perguruan tinggi harus menerapkan prinsip listen and respond sehingga program CSR yang diberikan dapat sesuai dengan apa yang diperlukan oleh target sasarannya (Wijaya \& Krismiyati 2014). Dengan penerapan model cycle relations yang dikombinasikan dengan prinsip listen and respond serta pelaksanaan program CSR yang berkesinambungan (sustainability) oleh perguruan tinggi, maka program tersebut terbukti telah berjalan dengan baik dan berimbas pada peningkatan intake bagi perguruan tinggi tersebut. 


\section{SIMPULAN, KETERBATASAN DAN SARAN Simpulan}

Secara garis besar, dari hasil penelitian ini dapat disimpulkan bahwa semua perguruan tinggi yang terlibat dalam penelitian ini telah melakukan kegiatan USR dalam berbagai bentuk mulai dari pemberian pelatihan, seminar ataupun kegiatan yang berdampak langsung terhadap masyarakat. Selain itu ada juga kegiatan yang diwujudkan melalui kegiatan beasiswa. Dengan kata lain, dalam kurun satu tahun mereka juga mendengarkan apa yang menjadi kebutuhan target sasaran mereka dan mewujudkannya dalam berbagai bentuk kegiatan agar lebih tepat sasaran. Secara singkat, model cycle relation yang diimplementasikan berpengaruh terhadap peningkatan intake perguruan tinggi karena hampir semua perguruan tinggi mengalami kenaikan intake antara 5 - 15 persen.

\section{Keterbatasan}

Penelitian ini telah diusahakan dan dilaksanakan dengan prosedur ilmiah, namun masih mempunyai keterbatasan yaitu factor-faktor yang mempengaruhi intake suatu perguruan tinggi dalam penelitian ini hanya terdiri dari tiga variabel yaitu pengajar/mahasiswa/alumni, masyarakat (sekolah/komunitas/orang tua) dan juga siswa SMA/SMK, sedangkan masih banyak faktor lain yang mempengaruhi intake dari suatu perguruan tinggi. Penelitian ini akan berdampak lebih besar jika melibatkan masyarakat pengguna lulusan perguruan tinggi sehingga tidak hanya terbatas di bidang akademik saja. Jadi keterbatasan lain dari penelitian ini adalah luasnya jangkauan geografis dari subjek penelitian, akan lebih bagus seandainya tidak hanya dilakukan di Jawa Tengah, jadi akan bisa melihat hasil uji coba di berbagai daerah untuk melihat generalitas hasilnya.

\section{Saran}

Sekolah sebagai pemasok intake perguruan tinggi merasakan kontribusi nyata dari kegiatan ini. Satu hal yang paling menarik adalah seberapapun teratur dan matangnya perencanaan mereka dalam melaksanakan kegiatan USR, peran guru di sekolah tidak bisa dipandang sebelah mata karena mereka sedikit banyak mempengaruhi siswa untuk memilih perguruan tinggi. Penelitian ini memberikan kontribusi terhadap literatur khususnya dalam program Corporate/University Social Responsibility dan dampak yang dihasilkan dari adanya program tersebut bagi berlangsungnya sebuah universitas. Secara umum, penelitian ini juga memberikan gambaran tentang model pelaksanaan CSR yang bisa diadaptasi untuk berbagai kegiatan yang berdampak bagi institusi laba ataupun nirlaba. Untuk penelitian selanjutnya bisa diteliti lebih lanjut dengan studi perbandingan ataupun longitudinal guna melihat seberapa besar dampak model cycle relations jika diimplementasikan dalam jangka waktu tertentu. Selain itu juga bisa dilihat lebih lanjut tentang peranan masing-masing aktor dalam model ini dan sampai sejauh mana dampak peranannya terhadap peningkatan intake bagi perguruan tinggi. Penelitian ini juga bisa 
dikembangkan lebih lanjut untuk melihat seberapa dampak kegiatan pertanggungjawaban sosial universitas terhadap citra dari sebuah universitas dari sudut pandang masyarakat.

\section{DAFTAR PUSTAKA}

Altbach, Philip G, Liz Reisberg, dan Laura E Rumbley. 2009. "Trends in Global Higher Education : Tracking an Academic Revolution." UNESCO 2009 World Conference on Higher Education. https://doi.org/10.1016/j.bse.2004.04.006.

Carrington, Peter J., John Scott, dan Stanley Wasserman. 2005. Models and methods in social network analysis. Cambridge University Press. https://doi.org/10.2277/0521809592.

Dahan, Gresi Sanje, dan Isil Senol. 2012. "Corporate social responsibility in higher education institutions : Istanbul Bilgi University case.” American International Journal of Contemporary Research 2 (3): 95-103.

Daulay, Pardamean. 2012. "Tanggung jawab sosial universitas terbuka dalam pencapaian MDGs.” Repository Universitas Terbuka, 2012.

Elkington, John. 1998. Cannibals with Forks: the Triple Bottom Line of 21 st Century Business. Conscientious Commerce. https://doi.org/0865713928.

Firdausy, G.M. 2009. Tanggung jawab sosial universitas (usr) dan pengalaman ristek dalam membangun masyarakat berbudaya iptek.

Hanneman, Robert a, dan Mark Riddle. 2005. Introduction to Social Network Methods. Riverside, CA: University of California, Riverside. On-line textbook. https://doi.org/10.1016/j.socnet.2006.08.002.

Harahap, Muchtar Effendi. 2014. "Perkembangan CSR di Indonesia." muchtareffendiharahap.blogspot.com. 2014.

Hornby, A.S. 1995. Oxford Advanced Learner's Dictionary. 5ed. Oxford University Press, Incorporated.

Nasongkhla, Jaitip, Shu Hsiang Cheng, dan J. Ana Donaldson. 2015. "University Social Responsibility (USR): Identifying an ethical foundation within higher education institution." Turkish Online Journal of Educational Technology 14 (4): 165-72.

Pemerintah Republik Indonesia. 2007. "Undang-Undang Nomor 40 tahun 2007 tentang Perseroan Terbatas."

Porter, Michael E., dan Mark R. Kramer. 2002. "The competitive advantage of corporate philanthropy." Harvard Business Review. https://doi.org/10.1177/0007650306297941. 
Scott, J. 2000. "Social network analysis: A handbook." SAGE Publications.

Suhayati, E. 2011. "Penerapan corporate social responsibility untuk meningkatkan citra universitas." Majalah Ilmiah Unikom 7 (2): 157-66.

Tanudjaja, Bing Bedjo. 2006. "Perkembangan corporate social responsibility di Indonesia." Nirmana 8 (2): 92-98.

Topal, R. Seminur. 2009. "CSR in Universities Around the World." Social Responsibility Research Network. 2009.

Widyantoro, Agus, dan M. Hadi Subhan. 2009. Tanggung jawab sosial institusi perguruan tinggi (institution social responsibility) sebagai upaya mewujudkan sustainablity development bagi masyarakat lingkar kampus. Diedit oleh Universitas Airlangga. Surabaya: Universitas Airlangga.

Wijaya, L.S, dan Krismiyati. 2013. "MPR strategies modelling for increasing student's intake at private universities in central java-Indonesia." Research Journal of Arts, Science and Commerce 4 (3).

2014. "Penyusunan model program corporate social responsibility (CSR) di perguruan tinggi kota salatiga dalam upaya meningkatkan intake perguruan tinggi." Jurnal Ekonomi dan Bisnis 17 (3): 141-54. 